\title{
Lessons of a Peace Process
}

\author{
Seán Lynch \\ H Block 5, Long Kesh
}

A peace process does not begin by some miraculous stroke of luck or genius. It requires conditions that need to be created and a series of steps are necessary to keep it alive and working towards a negotiated peace settlement. As Gerry Adams has pointed out:

Peace does not come in one great and all encompassing gesture. It requires a process ... it requires lateral moves by the all the principal parties to a conflict. It requires that gestures of goodwill be responded to and built upon; that, above all, they should not be arrogantly dismissed or thrown back.

The resolution of the South African conflict is often cited as an example for the current Irish peace process. Interestingly, the requirements outlined by Adams are illustrated in a recently published book, Tomorrow Is Another Country by Allister Sparks (Heinemann, f7.99), which gives an account of the South African peace process.

The first tentative steps in the South African peace process began when Nelson Mandela and an official from the South African government met in 1985. Throughout the mid 1980s, the world watched in horror as South Africa slipped further into violent conflict between the South African government and the liberation movement, particularly the ANC, struggling to end apartheid. However, throughout this period, before the rest of the world knew anything of it, the future of South Africa was being explored in secret conversations in hospitals, prisons, and a cabinet minister's home. These conversations were between government officials and the most famous political prisoner in the world, Nelson Mandela.

The struggle by the ANC to demolish the apartheid system had begun over 40 years earlier, initially through mass mobilisation, boycotts, and strikes. However as the state became more repressive, the ANC began the armed struggle in 1961, with Nelson Mandela as the first chief of staff of its army, Unkhonto We Sizwe (Spear of the Nation). A number of years later, he was arrested, put on trial for treason, and sentenced to life imprisonment. He said during his trial that: 'the armed struggle was imposed upon us by the violence of the apartheid regime.'

By the early 1980s, the anti apartheid struggle as a whole had captured the attention of the world. The South African government was under growing international pressure as nations across the globe began to impose economic sanctions on Pretoria.

Faced with crisis at home and pressure from abroad, P.W. Botha and his government hoped to alleviate its difficulties by means of a dual strategy. On the one hand, they employed greater repressive measures to defeat black 
resistance to the regime. On the other, they were trying to use the secret talks with Mandela as a counter-insurgency tactic. Their intention was to isolate Mandela from his imprisoned comrades and the external leadership of the ANC by offering him a conditional release from prison in the hope he could be persuaded to broker a political arrangement with other black leaders prepared to be used as puppets of the apartheid regime. In this way, opposition to apartheid would be divided and thrown into disarray, while the apartheid regime would gain a veneer of legitimacy without any fundamental change.

Mandela was not fooled by the government's strategy. He held strong, refused the terms of his release, and announced that, as a disciplined member of the ANC, he supported its policies, strategies, and tactics. He sent a message to the government stating his view that negotiation, not war, was the path to a final solution of the conflict. He stressed: 'Only free men can negotiate, prisoners cannot enter into contracts.'

Mandela's analysis during the mid 1980s was that the South African struggle for freedom could be best pushed forward through a negotiated settlement, and that, if dialogue between the government and the ANC did not start soon, both sides would be plunged into a darkness of repression. However, whilst Botha was not prepared to begin genuine talks with the ANC towards the dismantling of the apartheid system, there were those within the South African government who recognised that a solution to the conflict could only be found by entering into dialogue with the ANC. Despite the government's strategy, the secret meetings continued. In 1986, the Minister of Justice, Kobie Coetsee, visited Nelson Mandela in a prison hospital. Mandela outlined to Coetsee that he believed a military stalemate existed and that the time had come to start talks on resolving the conflict.

The meetings between the Minister of Justice and Mandela continued throughout 1987 and 1988. Mandela continued to argue for talks aimed at finding a democratic political solution to begin. However Coetsee, on behalf of the South African government, argued that the ANC should fulfil a number of requirements before the ANC could enter into any talks with the government. Again Mandela held strong and rejected the government's approach of setting preconditions before talks. Finally, Mandela sought and was granted a visit with the state president, P.W. Botha. This meeting took place whilst the government was publicly stating that they would not talk to a 'terrorist' organisation like the ANC. The meeting failed to break the dead lock. It was becoming increasingly evident that no fundamental change would take place while Botha remained in power. Botha mistakenly thought he could defeat the ANC and placate the struggle of the oppressed masses by continuing a strategy of trying to reform apartheid. However, the only result of his intransigence was to strengthen the resistance of the black population and the ANC's insistence on negotiations between the government and the ANC.

An opportunity to break the impasse and move the peace process forward arose in 1989 when Botha, the major obstacle to progress, resigned as state president. The man who was to become a key figure throughout the subsequent 
Journal of Prisoners on Prisons, Vol. 7, No. 1, 1996.

negotiations, F.W. De Klerk, was elected as the new president of South Africa. De Klerk's conservative leanings dampened expectations of radical change. However, after he was briefed on the on-going secret talks between the still imprisoned Mandela and government officials, he granted Mandela's request to see him. Mandela outlined to him a number of issues the government needed to address if they were to demonstrate their genuine intentions of breaking the $\log$ jam and moving the process forward. He stressed that negotiations without preconditions between the government and the ANC should begin immediately. De Klerk reflected on the situation and saw change as not only necessary but inevitable. He decided, therefore, that a fundamental step in a new direction was required to overcome the developing crisis in the country. Unlike Botha, he was not prepared to freeze the process but took a quantum leap to break free of the old apartheid mindset. The giant step forward occurred on February 2 1992 when, in a major speech, De Klerk legalised a whole spectrum of liberation groups, announced the release of Nelson Mandela and many other political prisoners, and declared his readiness to enter into negotiations with all parties to work out a new democratic South Africa. All previous preconditions sought by the government from the ANC were dropped, thus opening up the opportunity for the process to develop.

De Klerk's imaginative move brought about one of the most important phases of the peace process in South Africa. The government had finally made the decision to engage proactively in the process, with the result that the process had reached the organic stage: taken on an irreversible dynamic and momentum of its own, leaving it difficult for any single force or individual to scupper it. This is the crucial step required from the British government to move forward the Irish peace process. Unless and until John Major, like De Klerk, comes on board and engages in the process, there is always the potential danger that every effort by those genuinely seeking a peace settlement will come to nothing.

Irrespective of an oppressor having taken imaginative steps, it would be a grave mistake to believe they will relinquish power easily through a process of negotiations. Mandela said of negotiations: 'The point which must be clearly understood is that the struggle is not over, negotiations themselves are a theatre of struggle, subject to advance and reverses as any other form of struggle.'

De Klerk's speech had demonstrated that the apartheid thinkers had come a long way but they were still not free from their ideological mindset. Despite De Klerk's seemingly progressive action, he was by no means a man who intended to negotiate himself out of power. His goal was to create a form of power sharing which, if implemented, would preserve a modified form of minority rule. He was completely opposed to the ANC's objective of majority rule, primarily because he saw that it would end white domination in a single stroke. In an effort to veto the ANC's objective, De Klerk's nationalist party hoped to prevent democratic change by building an anti-ANC alliance with the Inkatha party and other movements. In other words, De Klerk wanted to use these groups as a veto over fundamental change. De Klerk's tactic of maintaining power and trying to determine the outcome of negotiations 
through these groups was similar to Britain's use of the Orange card: that is, their attempt at preventing movement towards a democratic resolution to the conflict by making all progress subject to the unionist veto. However, as a response to the limited first steps taken by De Klerk, the ANC suspended its armed struggle in 1990 to show their good faith and commitment to developing the conditions for peace.

Whilst the organic stage of the peace process is a qualitative development, it can also foster a dangerous fragile stage, unleashing negative reactionary forces opposed to change and negotiations towards a democratic society. The emergence of a Third Force in South Africa, consisting of sections of the military establishment, vividly demonstrates this point. The strategy of the reactionary forces in South Africa was to organise and exploit racial differences, particularly Inkatha, in an effort to undermine and weaken ANC negotiating power and derail the peace process. A series of developments, including Third Force activities, evidence of De Klerk's possible complicity in such activities, his unwillingness to tackle these problems, and his intransigence in relinquishing white rule, called into question De Klerk's peaceful intentions and forced the negotiation process into crisis. Mandela accused the government of having a double agenda. They were using negotiations not to achieve peace but to secure their own petty political aims. Interestingly, De Klerk tried to use the issue of ANC arms to pursue his own political agenda and question the ANC's commitment. He accused the ANC of failing to disclose the locations of arms dumps and rebuke them for maintaining a private army. Mandela angrily responded that 'the ANC had suspended the armed struggle to show their commitment to peace, and weapons would be handed in only when the ANC was part of the government collecting the weapons, and not until then.'

As a consequence of the government's failure to resolve the crisis in the peace process, the ANC suspended talks and laid out a number of demands upon which they would re-enter them. With negotiations stalled, the ANC and its allies agreed on a policy of rolling mass action. This new tactic played a vital role in the ANC's overall strategic objectives. These were: (i) to provide a channel for the growing anger and frustration among the population with a lack of positive results from negotiations; and (ii) to maximise pressure on the government to take the necessary steps to break the log jam in the process. As a result of the increasing violence of the Inkatha party and other anti-democratic forces, and the success of the ANC's mass action campaign, De Klerk and his government were forced to abandon their strategy of pursuing an anti-ANC alliance, and instead had to adopt democratic principles and see agreement with the ANC towards finding a final solution. De Klerk finally agreed to accept the principle of majority rule, and reluctantly agreed to all of the demands laid down by the ANC, one of which was the release of 500 political prisoners. The path to a final agreement was eventually cleared.

The success of the ANC's mass action strategy underlines the need for all Sinn Féin activists and general nationalist supporters to mobilise and create a genuine sense of participation, responsibility, and ownership in the peace 
process. They must help shape and define it, maintain its momentum, and eventually allow nationalist representatives, like those of the ANC, to enter negotiations with strength and clear grass-roots support.

De Klerk's change in direction to find a final agreement with the ANC meant that the peace process in South Africa had reached the most important and final stage. Implacable enemies throughout the conflict had converged and were aligned within the basic framework of abolishing the old apartheid order and reconstructing a new democratic future for the country. Mandela's words at this juncture were: 'To make peace with one's enemy, one must work with that enemy, and that enemy becomes your partner when seeking a final agreement.'

The final stages of negotiations were carried out with considerable good faith from both sides. Issues that had previously caused problems were resolved with a degree of flexibility and compromise, two of the essential requirements for bringing a peace process to a successful conclusion.

Whilst the details of the South African peace process are different from the Irish peace initiative, there are many parallels and general rules that apply to both peace processes. The South African example demonstrates the steps required to ensure the survival and success of the faltering Irish peace process. John Major's government needs to follow the courageous path upon which De Klerk embarked and positively engage in the process with vision and imaginative thinking. Major must take the decisive step and initiate all-party negotiations that tackle the fundamental causes of conflict in the six counties. The South African peace process was protracted, fragile, and dangerous, but it proved that a conflict situation can not be resolved without the major protagonists showing courageous leadership, being prepared to take risks, and eventually getting around the table and tackling the core issues of the problem. Unless John Major does likewise in Ireland, the main difference between the South African and Irish peace processes will be that of success and failure.

The central condition highlighted throughout Allister Sparks' book is that of engaging in political dialogue. Only through dialogue did the South African peace process get off the ground and create the opportunity for the ANC and the South African government to break down barriers and stereotyped images of each other. Dialogue was crucial to building trust and confidence between both parties, enabling them to overcome crises and problems that arose throughout the process. And only through dialogue within multi-party negotiations did all sides reach a final agreement and a peaceful democratic resolution of the conflict that had plagued the county for more than 40 years.

The British government has much to learn from the political realism of F.W. De Klerk. Rather than stall an inevitable process as Britain has done, De Klerk had the strength of his political convictions to stay with the developing process and bring about a resolution of the conflict in South Africa. Perhaps, someone should send John Major a copy of Allister Sparks' book. 